\title{
Wealthy Women and Legacy Hunters in Late Imperial Rome*
}

\author{
Elke Hartmann
}

"The noble lady Aurelia had dressed in her best for the ceremony of signing her will. When Regulus arrived to witness her signature, he asked her to leave these clothes to him. Aurelia thought he was joking, but he pressed the point in all seriousness, and to cut a long story short, he forced her to open the will and leave him what she was wearing." 1 With this anecdote, Pliny the Younger offered an introduction to the peculiar practice of hunting for legacies among carefully chosen prey: single, well-to-do women. He provides an interesting starting point for investigating the social position and perception during antiquity of rich and elderly women who, in late imperial Rome, bequeathed their property to men chosen outside the bonds of kinship through the legal instrument of the will, which allowed them to designate not only heirs (when they existed), but also legatees. In this extract, the narrator expresses his indignation at the persistence of Regulus, a particularly tactless upstart who with inappropriate obstinacy demands of the noble Aurelia that

This article was translated from the French by Michael C. Behrent and edited by Angela Krieger and Stephen Sawyer.

* I would like to thank Andreas Wittenburg for his work translating this article into French.

1. "Aurelia ornata femina signatura testamentum sumpserat pulcherrimas tunicas. Regulus cum uenisset ad signandum, 'Rogo,' inquit 'has mihi leges.' Aurelia ludere hominem putabat, ille serio instabat; ne multa, coegit mulierem aperire tabulas ac sibi tunicas quas erat induta legare." Pliny the Younger, Letters and Panegyricus, trans. Betty Radice (Cambridge: Harvard University Press, 1969), 1:2.20.10-11. On this passage, see in particular Jan Willem Tellegen, The Roman Law of Succession in the Letters of Pliny the Younger (Zutphen: Terra Publishing, 1982), 50-60. 
she leave him her most beautiful clothes. These tunics, which were probably made out of silk, were quite valuable. ${ }^{2}$

The word that contemporaries used to describe Regulus's behavior was captatio. Originally applied to bait-fishing and snare-hunting, the term refers to the practices of legacy hunters-also known as testament hunters-who lured rich testators into their trap. ${ }^{3}$ References to legacy hunters first appear with great regularity in our sources beginning in the late first century BC and the first two centuries AD. ${ }^{4}$ Their frequency attests to the significance of the phenomenon. Yet this purely quantitative observation reveals little about why the practice emerged during this period. It also acts as a reminder of the need to be attentive to the nature of one's sources, which in this instance are primarily literary satires. This raises

2. The value of fabric is often neglected by contemporary historiography. On the cut and value of silk clothing, see: Wilhelm Adolf Becker, Gallus, oder Römische Scenen aus der Zeit des Augustus zur genaueren Kenntniss des römischen Privatlebens (Leipzig: F. Fleischer, 1863), 3:203-19; Berit Hildebrandt, "Seide als Prestigegut in der Antike," in Der Wert der Dinge. Güter im Prestigediskurs, eds. Berit Hildebrandt and Caroline Veit (Munich: H. Utz, 2009), 183-239.

3. On the metaphor of hunting in a comparable context, see Martial, Epigrams, ed. and trans. D. R. Schackleton Bailey (Cambridge: Harvard University Press, 1993), 1:4.56 and 2:9.88. On terminology, see: Agnes R. Mansbach, "Captatio: Myth and Reality," (PhD diss., Princeton University, 1982), 2; Edward Champlin, Final Judgments: Duty and Emotion in Roman Wills, 200 B.C.-A.D. 250 (Berkeley: University of California Press, 1991), 87. The expression captare testamentum is first found in Horace's satires: "Well, I have told you, and I tell you now. Fish craftily in all waters for old men's wills, and though one or two shrewd ones escape your wiles after nibbling off the bait, do not give up hope, or drop the art, though baffled." Horace, Satires, Epistles, and Ars Poetica, trans. H. Rushton Fairclough (Cambridge: Harvard University Press, 1926), 2.5.23-24. The practice thus named was already mentioned by Plautus in The Braggart Soldier (Miles gloriosus): "On my death I'll distribute my goods among my relatives, I'll divide them among them. They'll be with me, look after me, visit me to see how I am and what I want. Before it's light they're present and ask me if I've slept well. Those who send me gifts I treat as my children.” Plautus, The Braggart Soldier, in Plautus, ed. and trans. Wolfgang de Melo (Cambridge: Harvard University Press, 2011), 3:705-15. See, too, Cicero's Paradoxa Stoicorum: "Or is there any doubt about the slavery of people who are so covetous of cash that they refuse no condition of the harshest servitude? The hope of a legacy-what harshness of service does it not undertake? What nod from a rich old man without children does it not attend to? It makes conversation when it suits him, executes all his commissions, follows him about, sits at his side, makes him presents; which of these is the action of a free man? Which indeed does not make an indolent slave?" Cicero, Paradoxa Stoicorum, in Cicero, trans. H. Rackham (Cambridge: Harvard University Press, 1942) 4:39. Furthermore, in Pro Cluentio, Cicero observes: "By the will of P. Aelius his kinsman was disinherited, and the defendant, though quite a stranger, was made heir." Cicero, Pro Cluentio, in The Speeches, trans. H. Grose Hodge (Cambridge: Harvard University Press, 1993), 162. On this topic, see Koenraad Verboven, The Economy of Friends: Economic Aspects of "Amicitia" and Patronage in the Late Republic (Brussels: Latomus, 2002), 198.

4. With later authors, however, such examples vanish. See Mansbach's chart in "Captatio: Myth and Reality," appendices A and B, pp. 118-35, which uses the list drawn up by Dankwart Schmid, "Der Erbschleicher in den antiken Satiren," (PhD diss., Tübingen University, 1951). An overview of uses can also be found in Champlin, Final Judgments, appendix 4, pp. 201-2. 
the problem of the relationship between the authors' use of literary topo $i$ and concrete social practices shaped by juridical structures.

Nineteenth-century historians, who were the first to specialize in ancient mores, devoted considerable attention to legacy-hunting practices, which authors of the early Principate so frequently describe. ${ }^{5}$ Ludwig Friedländer, author of the monumental Roman Life and Manners (originally published in 1865), notes that legacy hunters-whom he condemned on moral grounds-were symptomatic of the times, particularly in Rome itself. He considered their brazen dishonesty-the fact that they concealed their self-interest beneath a friendly façade- to be particularly reprehensible. ${ }^{6}$

While Friedländer considered legacy hunting to be a verified social practice, recent research has questioned the reality of this phenomenon, which is primarily described in poetic texts. ${ }^{7}$ Agnes Mansbach in particular has adopted this hypercritical approach. In her view, the satirical and moral literature elevating captatio to the rank of a literary topos does not allow for the conclusion that such a practice actually existed. ${ }^{8}$ Rather, these narratives belong to a broader ethical discourse that condemned the greed of amici when it came at the familia's expense. ${ }^{9}$ The main characteristic of such scholarship is to radically call into question the social referent of these narratives. Moreover, unlike ancient writers, these scholars refuse to focus exclusively on the legacy hunters themselves, instead emphasizing the reciprocal relationship between the captatores and the testators who succumbed to their charms. They draw attention to how little this relationship differed from bonds between amici. ${ }^{10}$ From this perspective, it was only the negative lens through which contemporaries viewed these relationships that led them to characterize legacy hunting

5. Ludgwig Friedländer, Darstellungen aus der Sittengeschichte Roms in der Zeit von Augustus bis zum Ausgang der Antonine (Leipzig: Hirzel, 1919), 1:248-53; Richard P. Saller, Personal Patronage Under the Early Empire (Cambridge: Cambridge University Press, 1982), 124-25; Keith Hopkins, "Wills and Legacy Hunters," Death and Renewal (Cambridge: Cambridge University Press, 1983), 235-47; Mireille Corbier, "Idéologie et pratique de l'héritage $\left(\mathrm{I}^{\mathrm{er}}\right.$ s. av. J.-C.-II ${ }^{\mathrm{e}}$ s. ap. J.-C.)," Index 13 (1985): 501-28; and Verboven, The Economy of Friends, 197-200. The latter's analysis refers primarily to Champlin, Final Judgments, 87102, which in turn refers to Mansbach, "Captatio: Myth and Reality."

6. Friedländer, Darstellungen aus der Sittengeschichte Roms, 1:248. See the English translation, Roman Life and Manners Under the Early Empire, trans. Leonard A. Magnus (London: Routledge \& Kegan Paul, 1907; repr. 1965), 1:213: "It was an open secret at Rome that the most wide-awake and zealous of the officiosi or dandies, were professional ghoulsin-waiting [i.e., legacy hunters], flattering their expected testators, anticipating astrologically their decease, bribing doctors to hasten death on ... The extent of this professional fore-measuring of dead men's shoes casts a lurid light on the mendacity of the Rome of that day."

7. See, notably: Mansbach, "Captatio: Myth and Reality," particularly p. 114; Champlin, Final Judgments, 96 and 100-2, particularly p. 100: "There is almost no factual evidence for the existence of captatio as a historical phenomenon." Along the same lines, see Verboven, The Economy of Friends, 197-200.

8. According to Mansbach, the phenomenon is primarily addressed in erudite literature.

See "Captatio: Myth and Reality," 3-4.

9. Ibid., 114.

10. See Verboven, The Economy of Friends, 180. 
as a distinct but degenerate form of friendship. According to Edward Champlin, this critical perception is what ultimately defined legacy hunting. "Captatio," he writes, "lies in the eye of the beholder." 11

Despite these methodological innovations, current research neglects a key feature of the sources: in many texts, the individuals targeted by legacy hunters and marriage swindlers were single women-unmarried, separated or widowed. Even Friedländer ignores the numerous texts-Martial's Epigrams comes to mind-in which a man attempts to seduce a solitary older woman. ${ }^{12}$ In his vast study of Roman women, John Percy Balsdon deals only in passing with the individuals whom legacy hunters desired, adopting the satirical stance of the poems that, he maintains, present women as perpetual objects of ridicule. ${ }^{13}$ According to Niklas Holzberg, a leading Martial specialist, the poet uses the theme of sexuality, which figures so prominently in the Epigrams, to transcend the discrepancy between official norms and social practices that are attested to elsewhere. ${ }^{14}$ Jens-Uwe Krause, the author of an exhaustive study on the social and economic position of widows, confines himself to economic considerations. Overall, he concludes, widows were gradually becoming poorer. While this finding is accurate if one looks at society as whole, it fails to consider the specific circumstances of the rich widows described by ancient writers, particularly authors of epigrams. ${ }^{15}$ This brief historiographical overview points toward aspects of the topic that contemporary research has neglected and toward new methodological principles to explore.

Indeed, while these circumstances could befall elderly men, who were also targeted by legacy hunters, they come into particularly sharp focus in instances where women are concerned. This is firstly due to a peculiarly Roman principle of social and legal organization: since they had a legal right to inherit and because they did not hold their property in community with their husbands, women often owned extensive patrimonies. Naturally, a woman's status could vary considerably, between single women-a very rare or, in any case, poorly documented condition, with the exception of the Vestals-and widows, who were emancipated from paternal authority. What did matter, however, was their right to dispose of their own patrimony while simultaneously being orba, or "lacking an heir"—a common situation,

11. Champlin, Final Judgments, 97.

12. See the general description of rich women who "wore the pants": Friedländer, Darstellungen aus der Sittengeschichte Roms, 1:278; Friedländer, Roman Life and Manners, 1:236-38.

13. John Percy Vyvian Dacre Balsdon notes: "The rich widow attracted the attention of every sort of gigolo and confidence trickster. Either she knew her power, and enjoyed the tyranny that she exercised, or she was ridiculously gullible.” John Percy Vyvian Dacre Balsdon, Roman Women: Their History and Habits (London: Bodley Head, 1962), 222. 14. Niklas Holzberg, Martial (Heidelberg: C. Winter, 1988), 54-55. Compared to earlier historiography, which viewed satirical verse as symptomatic of pervasive misogyny, Jean Gérard's approach marks an indisputable epistemological advance. See Jean Gérard, Juvénal et la réalité contemporaine (Paris: Les Belles Lettres, 1976), 260-64.

15. Jens-Uwe Krause does not dwell on rich widows and mentions the phenomenon of legacy hunting only in passing. See his Witwen und Waisen im Römischen Reich, vol. 2 of Wirtschaftliche und gesellschaftliche Stellung von Witwen (Stuttgart: F. Steiner, 1994), 40. 
meaning either that a woman had no legitimate children, had renounced her descendants or that her offspring had died before her.

The problem of widows thus raises the broader question of a uniquely Roman gender regime, which must be explained by integrating it into a more general reflection on the social and legal history of imperial Rome. There is also an imaginary dimension to the issue, which is tied to perceptions of relationships between older women and younger men that were concretized when the latter were granted the status of legatees. Though only the family circle could determine heirs, legatees expressed the testator's wider social network, cemented through amicitia. While it was perfectly honorable to become the legatee of an individual with whom one had longstanding ties, some legatees were judged unworthy because they had greedily acquired this status through intrigue or seduction. Roman society thus deemed the legacy hunter an illegitimate legatee on the basis of social conventions as much as law. Yet this consideration of the social imagination only brings one back to the question of gender, insofar as it draws on a representation of intergenerational sexual relationships. In this respect, the literary commonplace and representations of the Roman elite allow for a reflection upon the specific status of heirless women, while reinscribing this problem into Roman social and legal practices. In this way, the gender regime specific to this elite can also be reconstructed: the freedom enjoyed by elite women in their relations with men and the interplay between these relations and moral norms was illustrated with particular clarity by contemporary literature of the day.

According to some scholars_notably Mansbach, Champlin, and Koenraad Verboven-, captatio as a recurrent motif was confined to the literary tradition: in Champlin's view, it was seen by contemporaries as nothing more than a topos or a symbol of the wicked consequences of avarice and selfishness-which were not, as such, social practices. ${ }^{16}$ This article, however, considers this topos as embedded in historical reality: not as a direct transcription of real situations, but as the manifestation of a practice that actually existed and, possibly, as an attempt to influence this practice through normative judgments. When research no longer focuses exclusively on the legacy hunter alone, it becomes clear that captatio implied two parties. This article will address the rules governing this type of social relation ${ }^{17}$ as well as the specific problems resulting from the fact that it was a relationship between a man and a woman.

To this end, I will devote particular attention to Martial's epigrams (c. 40102 AD). Like his younger colleague Juvenal (c. 60-140 AD), Martial was deeply concerned with the phenomenon of captatio. ${ }^{18}$ The epigrams examined here have been selected for their exemplary value and present wealthy women as particularly sought after by legacy hunters. From this perspective, it is first necessary to examine the specificity of the phenomenon of legacy hunting, for which the satirical

16. Champlin, Final Judgments, 102.

17. On this topic, see the hypotheses explored in ibid., 89.

18. For an overview of the main texts from antiquity in which this theme is addressed, see ibid., 201-2. 
literature provides the primary source. Next, the social conditions that made legacy hunting possible will be considered: at the time, legacy hunting was seen as a completely normal strategy for acquiring property. Two issues that have yet to be sufficiently examined will then be explored: first, the question of the social and financial position of single women; second, the question of childlessness (orbitas). Finally, these descriptions pose the question of the comic effect sought by poets: upon what literary clichés related to gender and distinct to Roman culture did they draw? To what extent does this comedic effect allow one to conclude that the male-female relations dramatized in this way were unique?

\section{The Relationship Between Legacy Hunting and Satirical Literature}

Insofar as this article attempts to explain how the representation of captatio in Martial's Epigrams improves one's understanding of Roman social and historical conditions and gender relations, the frequency of this theme in satirical literature must first be considered. As Martial's Epigrams are taken here as a full-fledged historical source, it is also necessary to ask if these texts may truly offer insight into social phenomena in general and legacy hunting in particular.

The fragmentary nature of the surviving texts makes it impossible to chart the history of specific literary topics or themes with any precision, just as it is difficult to describe their evolution before they ultimately disappeared. It is nonetheless noteworthy that captatio-though already addressed by Plautus (around 200 BC) in his Miles Gloriosus and present in the works of Horace and Lucian-is most often associated with the literature of the first and second century AD, particularly the poet Martial and his junior, Juvenal. ${ }^{19}$ This does not necessarily mean the theme appeared more frequently at this time. The reason might lie in the simple fact that poetic and especially satirical texts flourished in Rome under the reign of the early emperors, when poets had pride of place, were favorably received, and earned increasingly lucrative rewards from wealthy patrons. Moreover, it must be remembered that the theme of captatio was characteristic of a literary genre focused on human behavior and weakness, as was usually the case in Martial's Epigrams. Poets focusing on human conduct were particularly concerned with the self-interested actions undertaken in the struggle to climb the social ladder. Making one's fortune by hunting legacies was one such example. Needless to say, by observing these strategies, poets also addressed a concrete social issue. Martial's stock characters and the strategies they pursue can be used as reference points when considering comparable configurations and practices in other literary genres.

Martial's historical significance has been addressed in general terms by Holzberg, while Champlin specifically considers him from the perspective of 
captatio. ${ }^{20}$ Holzberg tends to deny the documentary value of Martial's representations of daily Roman life. ${ }^{21}$ Like any literary text, he argues, the epigrams must be read as constructions rather than as a mirror of reality. Yet one must take into account the fact that Martial's treatment of human conduct, social practices, and characters had to be recognized and accepted by the audience and readers that he sought to entertain. Otherwise, one would have to argue that poets created phenomena like the captatio from thin air. ${ }^{22}$ If they did, then why? The degree to which these portrayals are exaggerated and distorted remains, however, difficult to assess, except in cases when material from poetry and prose can be compared, allowing one to identify the diversity of Roman social structure under the Principate. Moreover, captatio was discussed not only in satirical texts, but also by classic authors such as Seneca, Pliny the Younger, and Tacitus. One reason why references to legacy hunting were relatively rare may be that the charge of captatio was "far more convenient to bring than to prove." ${ }^{23}$ A further explanation could be that the latter authors, who were members of the wealthy elite, often profited from this practice, as did Pliny or Seneca. Consequently, they dealt with it as discreetly as possible. Romans, like Martial, who did not share these circumstances-at least not to the same degree-adopted a different attitude.

\section{Inheritance: A Commonplace Strategy for Acquiring Goods}

During the imperial period, it was easier to increase one's patrimony through inheritance (as well as through marriage or gifts) than through profits acquired from farming, financial transactions or paid labor. ${ }^{24}$ Although the importance given to

20. Ibid., 95.

21. Analyzing the style and composition of Epigrams as well as the way in which Martial engaged with elements and typology belonging to the literary tradition, Niklas Holzberg maintains that they should be read as pure fictions. See Niklas Holzberg, Martial und das antike Epigramm (Darmstadt: Wissenschaftliche Buchgesellschaft, 2002), 15. The poet is no longer considered a person, but an author, who attributes fictitious voices to his various personae. Though this is undoubtedly a useful way to arrive at a more precise understanding of Martial's Epigrams, its denial of real life seems too extreme. Other recent studies of Martial do not so adamantly reject the connection of Epigrams to reality. On the one hand, John Patrick Sullivan, in Martial, the Unexpected Classic: A Literary and Historical Study (Cambridge: Cambridge University Press, 1991), and Art L. Spisak, in Martial: A Social Guide (London: Gerald Duckworth, 2007), tend to see Martial's poetry as a "manual" or "guide" reflecting its readers' ethical outlook and preoccupations; on the other hand, William Fitzgerald, in Martial: The World of the Epigram (Chicago: University of Chicago Press, 2007), and Victoria Rimell, in Martial's Rome: Empire and the Ideology of Epigram (Cambridge: Cambridge University Press, 2008), consider Martial's interest in social critique and the broad palette of issues he addresses. 22. Fabian Goldbeck, Salutationes. Die Morgenbegrïßungen in Rom in der Republik und der frühen Kaiserzeit (Berlin: Akademie Verlag, 2010), 36.

23. Champlin, Final Judgments, 96.

24. Sigrid Mratschek-Halfmann, Divites et praepotentes. Reichtum und soziale Stellung in der Literatur der Prinzipatszeit (Stuttgart: F. Steiner, 1993), 11 and 117. 
inheritance is, from today's perspective, far from obvious, it was characteristic of all ancient agrarian societies.

To better understand this situation, a few specific aspects of the Roman law of succession must be presented. It provided for two forms of inheritance rights. The oldest, first mentioned in the Twelve Tables of the fifth century BC, was the so-called intestate (ab intestato) succession, whereby the father (pater familias) passed on his estate as an inheritance (hereditas) to "his heirs," who were emancipated from paternal authority (heredes sui). If he was married under the provisions of uxor in manu, then his spouse also counted as one of "his heirs." 25 In this case, the heirs immediately took the place of those from whom they inherited. Yet the danger of this earlier approach was to divide estates from generation to generation, notably in the case of landed property. It was undoubtedly for this reason that the freedom to testate - the second form-became succession law's dominant principle beginning in the early republic. Through a testament (ex testamento), testators could bequeath their goods to one or more individuals of their choice. ${ }^{26}$ With the onset of testaments, intestate succession ceased to apply. Over time, various restrictions were introduced. For instance, testators could not simply ignore their closest family members unless they had been previously disinherited. The right to testate belonged to free male citizens, as well as to free women who were not under a man's authority (in manu), with a tutor's permission if need be. ${ }^{27}$ While any free citizen could be made an heir (as could certain slaves, provided they had been emancipated), women were subject to a number of restrictions, even though these did not apply in the late imperial period considered here. Through testaments, testators could make almost unlimited bequeathals. ${ }^{28}$

In Rome, these bequeathals included a particular kind of gift known as legata, which were primarily directed at spouses as well as friends and family. Legata consisted of concrete goods (whether mobile or immobile) as well as financial claims, including dowry restitutions and debt emancipation. However, by the second century AD, legata amounts were limited by law, presumably, as Max Kaser argues, to prevent estate dispersal. ${ }^{29}$ Since the nineteenth century, historians have disagreed over which social classes and in what proportion Romans made legata through testaments. Recently, Yaakov Stern has criticized-rightly, in my

25. Max Kaser, Das Römisches Privatrecht: Ein Studienbuch (Munich: C. H. Beck, 1979), 264-65.

26. Ibid., 266.

27. Ibid., 281. Even though they were not legally permitted to do so in principle, women could easily become testate if they first followed the purely formal procedure of coemptio with a trustworthy man and then received authorization to be emancipated from manus (remanicipatio) and manumissio.

28. Ibid., 299-300.

29. Ibid., 304. Similarly, one must also include in the category of legacies what was commonly known as "fideicommissum" (fidei commissum), which originally was an informal request made by the testator in a testament to an individual considered trustworthy enough to make a financial payment or gift to another individual. Beginning in the middle of the first century AD, legata and the fideicommissum merged. Justinian claimed the difference between them was purely formal. Justinian Code, 6.43.2. 
view-Champlin's opinion that there was a clear preference for intestate succession in late imperial Rome. ${ }^{30}$ One's position on this issue largely depends on how one judges the reliability and significance of these testimonials. In this, as in many other cases, a purely quantitative assessment of this phenomenon is difficult to reach. For this reason, I shall attempt to describe in more qualitative terms the advantages of testamentary practices for the parties involved.

The Roman urban elite of the late empire was particularly dependent on testaments for acquiring property. This was true for several reasons. One of the traditional opportunities for acquiring riches-war-had grown significantly less frequent than during the republican period. ${ }^{31}$ Moreover, it was still considered unbecoming for an aristocrat to practice a trade or engage in commerce. As they mostly consisted of real estate, the patrimonies of many Romans were relatively inaccessible. However, by the late republic, there was a constant demand for liquidity (for spending and honoring one's clients) and for outward signs of prestige (dishes, clothes, furniture, etc.)—needs arising from the social obligation for conspicuous consumption. ${ }^{32}$ It was precisely this kind of spending that made members of the upper ordines dependent on bequeathals. Legacy hunting was not a poor man's business: even Romans as wealthy as Seneca stood accused, according to Tacitus, of hunting for legacies. Several times in his Letters, Pliny the Younger refers to legacies that enabled him to enjoy considerable supplementary expenses. ${ }^{33}$

Legacies were traditionally transmitted through networks of amicitia that were based on reciprocal bonds. One's ability to engage in amicitia was the fruit of relationships of trust established over the course of a lifetime. In this way, one entered the regulated framework of exchange between gift-giver and gift-receiver. To be written into a testament constituted just retribution for services rendered (including, among other good deeds, care for the elderly) and above all provided an opportunity to express solidarity and affection. This explains why the testaments of many members of the elite made the emperor their legatee. Through this device, Roman elites conveyed their commitment to the dynasty. ${ }^{34}$

30. Champlin, Final Judgments, 101; Yaakov Stern, "The Testamentary Phenomenon in Ancient Rome," Historia. Zeitschrift für Alte Geschichte 49-4 (2000): 413-28.

31. Dieter Nörr, "Planung in der Antike. Über die Ehegesetze des Augustus," in Freiheit und Sachwwang. Festschrift zu Ehren von Helmut Schelskys, ed. Horst Baier (Opladen: Westdeutscher Verlag, 1977), 309-34.

32. Beate Wagner-Hasel, "Verschwendung und Politik in Rom. Überlegungen zur politischen Semantik des Luxuskonsums in der späten Republik und frühen Kaiserzeit," Historische Anthropologie 10-3 (2002): 325-53.

33. By examining senatorial families, Israel Shatzman shows that patrimony was often acquired and expanded through testaments from friends and individuals beholden to them. See: Israel Shatzman Senatorial Wealth and Roman Politics (Brussels: Latomus, 1975), particularly pp. 409-11; Tacitus, Annals 13-16, trans. John Jackson (Cambridge: Harvard University Press, 1937), 13.42; Pliny the Younger, Letters and Panegyricus 1:5.1; and the commentary of Andrew D. E. Lewis, "The Dutiful Legatee: Pliny, Letters V.1," in Beyond Dogmatics: Law and Society in the Roman World, eds. John W. Cairns and Paul J. du Plessis (Edinburgh: Edinburgh University Press, 2007), 125-38.

34. Jochen Martin, "Zur Anthropologie von Heiratsregeln und Besitzübertragung. 10 Jahre nach den Goody-Thesen," Historische Anthropologie 1-1 (1993): 149-62, espe- 


\section{Women's Wealth and Childlessness}

Why do many sources present women as the preferred prey of legacy hunters? Were they particularly wealthy? Did their patrimony have special qualities? As I've already demonstrated, it is generally accepted that during the late republican and early imperial periods, women often owned significant patrimonies. ${ }^{35}$ Yet estimating the size of men's or women's patrimonies in numerical terms remains extremely difficult. It is very likely, as Krause maintains, that women were considerably less wealthy than men overall. ${ }^{36}$ Regrettably, this conclusion does not improve one's understanding of distribution structures or patterns of elite property transmission. To the extent that there exists no systematic study of women's wealth during the imperial period, its scale and origin can unfortunately only be estimated in very general terms. ${ }^{37}$

Women's opportunities for acquiring and enlarging their patrimony probably differed little from those available to men: there has been evidence of a number of women who increased their wealth through revenue from real estate and farming, the sale of food commodities, commerce, skilled labor (brick-making, for instance) or financial transactions. ${ }^{38}$

Of course, women also received family property, such as dowries (the restitution and reimbursement of which were expected when a marriage ended), through

cially the quote on 152; Brent D. Shaw and Richard P. Saller, "Close-Kin Marriage in Roman Society?" Man 19-3 (1984): 432-44.

35. Krause, Witwen und Waisen, 215-16.

36. Ibid., 215-16. The fact that fewer female than male testaments are mentioned in the sources does not necessarily mean that women's patrimonies were smaller, as Champlin implies (Final Judgments, 46-59). This example demonstrates the extent to which the interpretation of data, which is after all difficult to generalize, is shaped by scholarly prejudice, including the frequent assumption that women in antiquity were socially disadvantaged. Krause, for example, presumes that widows were usually poor.

37. In her prosopography of the Roman Empire's wealthiest citizens, MratschekHalfmann gives the example of about fifty women who, in the first century AD, were described by contemporaries as "particularly wealthy": Divites et praepotentes, nos. 194, $221,223,224,227,230,232,238,244,248,259$, etc. Nevertheless, she does not focus on the specific nature of female wealth. The fact that many of the women on her list lived during the second half of the first century AD may have to do with source preservation, but it may also indicate a greater incidence of examples from this period. MarieTherèse Raepsaet-Charlier lists women of the senatorial order, though she refrains from discussing the status of their patrimony. See Marie-Thérèse Raepsaet-Charlier, Prosopographie des femmes de l'ordre sénatorial, I'r-II' siècles (Louvain: Peeters, 1987), 2 vols. Existing scholarship undoubtedly needs to conduct more careful analysis of the social characteristics of rich and famous women in order to arrive at more nuanced conclusions, as these are often based on widely held prejudices.

38. Consider, for example, the case of Domitia Lepida, who raised fish and participated in the grain trade. See: Mratschek-Halfmann, Divites et praepotentes, p. 102, no. 110; John H. D’Arms, Commerce and Social Standing in Ancient Rome (Cambridge: Harvard University Press, 1981), 75-76 and 78. On brick-making, see Mratschek-Halfmann, Divites et praepotentes, 103-4 and bibliography. 
inheritance or testamentary bequeathals. ${ }^{39}$ What magistrates called mundus muliebris-i.e., clothes and jewelry, as well as furniture and household utensils-formed an important component of women's patrimony. ${ }^{40}$ These items were not only essential for projecting a luxurious lifestyle, but were also considerably valuable in their own right. In particular, unlike real estate, their worth could be easily calculated in terms of divisible unities (i.e., by specie), ${ }^{41}$ which is why captatores particularly coveted these objects. The distinct character of women's patrimony thus explains why legacy hunters were especially interested in women.

A second reason might lie in the fact that affluent women were often richer than affluent men. Indeed, women were not required to spend large sums on the cursus honorum, such as the organization of public games expected of the Aediles. ${ }^{42}$ Naturally, unmarried women were even less exposed to these expenses. Furthermore and contrary to what is often maintained, girls were not particularly disfavored by inheritance law compared to their brothers. ${ }^{43}$ While Roman law did favor the

39. See Krause, Witwen und Waisen, 216 (on dowry restitution) and 49 (on dowry amounts). Krause argues that very large dowries (in the range of several hundred thousand sesterces) were a topos. Susan Treggiari believes, perhaps rightly, that such dowries were real. See Susan Treggiari, Roman Marriage: Iusti Coniuges from the Time of Cicero to the Time of Ulpian (Oxford: Clarendon Press, 1991), 345-46. Pliny the Younger explained that he could receive three million sesterces, intended for land acquisition, from his mother-in-law (possibly in the form of a land guarantee). He himself did not have such a sum available because his own patrimony was invested in real estate. See Pliny the Younger, Letters and Panegyricus 1:3.19.7.

40. Krause, Witwen und Waisen, 88-89. After initially failing at maritime commerce, Trimalcin was able to survive thanks to the high value of his wife's jewels and clothes. See Petronius, Satyricon, trans. Michael Heseltine, in Petronius: Satyricon; Seneca: Apocolocyntosis (Cambridge: Harvard University Press, 1913), 76.3. The value of the jewels owned by Lollia Paulina, Emperor Caligula's wife-who, Tacitus recounted, was forced to commit suicide in $49 \mathrm{AD}$-was estimated, according to Pliny the Elder, at forty million sesterces. See: Tacitus, Annals 4-12, trans. John Jackson (Cambridge: Harvard University Press, 1937), 12.22.2-3; Pliny the Elder, Natural History, trans. H. Rackham (Cambridge: Harvard University Press, 1960), 3:9.117; and Mratschek-Halfmann, Divites et praepotentes, p. 295, no. 93. According to Tacitus (Annals 13-16, 16.30), Servilia sold jewels and clothes that were signs of her rank in order to pay several magi. Pliny the Younger mentions "clothing, pearls, and jewels" as dowry articles (Letters and Panegyricus 1:5.16.7). 41. Juvenal refers to objects being pawned to finance a luxurious banquet. See Juvenal, Satires, in Juvenal and Persius, trans. Susanna Morton Braund (Cambridge: Harvard University Press, 2004), satire 11, 1-26.

42. Martial tells of a wealthy woman who sought a divorce after her husband was elected praetor (which required him to finance games). See Martial, Epigrams 2:10.41. On the other hand, Juvenal describes a praetor who attended the morning salutationes of rich women, hoping for a marriage or a testamentary inheritance. See Juvenal, Satires, satire 3, 125-126.

43. In footnote 206 on page 216 of Witwen und Waisen, Krause mentions a number of studies concluding that girls found themselves at a disadvantage compared to their brothers, though Krause himself does not emphasize this point. On women in inheritance law, see John A. Crook's summary, "Women in Roman Succession," in The Family in Ancient Rome: New Perspectives, ed. Beryl Rawson (London: Croom Helm, 1986,) 5882, particularly pp. 78-79. On forms of property transference, see: Richard P. Saller, 
agnatic circle of the male line ${ }^{44}$ when handing down patrimonies to the next generation, this did not necessarily disadvantage women belonging to the male line. Married women were also able to inherit from their own parents.

In the case of traditional in manu marriage, women could inherit from their husbands: widows received their share as quasi-daughters, since they had been made their husbands' dependents through marriage. In the more frequent instance of sine manu marriage, women could inherit as the daughters of their own fathers. ${ }^{45}$ According to Roman law under the Principate, women could request a separation (divortium) without justification. Not all women married, nor did they necessarily remarry following their husbands' deaths, even when doing so was legally desirable.

The fact that many women at this time remained single has not been specifically studied and may seem rather odd. Indeed, declining marriage, like refusing to procreate, violated expectations commonly associated with ancient agrarian societies. ${ }^{46}$ Some scholars maintain, often implicitly, that members of the Roman elite were concerned with little other than perpetuating their houses. ${ }^{47}$ Yet childlessness in the superior orders is frequently declared beginning in the late republican peri$\mathrm{od}^{48}$ and as such has been studied quite thoroughly. ${ }^{49}$ It is known that marriages, like adoptions, occurred within the ranks of the elite and that they were often intended less to maintain a family's biological and financial continuity than to forge relations of friendship with one's peers-in other words, to establish horizontal bonds. ${ }^{50}$ To this end, testamentary legacies played a decisive role: they confirmed

\footnotetext{
"Roman Heirship Strategies in Principle and in Practice," in The Family in Italy from Antiquity to the Present, eds. David I. Kertzer and Saller (New Haven: Yale University Press, 1991), 26-47; Martin, "Zur Anthropologie," 156-57 and 160.

44. On inheritance law, see Max Kaser, Das Römische Privatrecht: 2, new ed. (Munich: C. H. Beck 1971), §66, pp. 270-71. On the practice of renunciation, see: ibid., §69, p. 283; Mireille Corbier, "Divorce and Adoption as Roman Familial Strategies (Le divorce et l'adoption 'en plus')," in Marriage, Divorce, and Children in Ancient Rome, ed. Beryl Rawson (Oxford: Clarendon Press, 1992), 53.

45. On these questions, see Ann-Cathrine Harders's summary in Suavissima soror: Untersuchungen $z u$ den Bruder-Schwester-Beziehungen in der römischen Republik (Munich: C. H. Beck, 2008), 314.

46. Christiane Kunst, Römische Adoption. Zur Strategie einer Familienorganisation (Hennef: Clauss, 2005), 35-36.

47. "The first, typically Roman thought was, however, to put an end to the childlessness orbitas," writes Corbier in "Divorce and Adoption," 63. A strong desire for children is also implied by: Krause, Witwen und Waise, 39-40; Peter Thrams, "Kinderlosigkeit," Reallexikon für Antike und Christentum 20 (2004): 947-63.

48. Krause maintains that, in the Roman Empire, "many marriages (at least a fifth) remained childless." Krause, Witwen und Waisen, 103.

49. Keith Hopkins and Graham Burton show that, during the late empire, more traditional families had a higher reproduction rate than, say, the families of consules suffecti. See Keith Hopkins and Graham Burton, "Political Succession in the Late Republic," in Death and Renewal, 31-119. See also Angelika Mette-Dittmann, Die Ehegesetze des Augustus. Eine Untersuchung im Rahmen der Gesellschaftspolitik des Princeps (Stuttgart: F. Steiner, 1991), 210. On current controversies relating to research on the Roman family, see Harders's very clear synthesis in Suavissima soror, 10-11.

50. See, notably, Harders, Suavissima soror, 82.
} 
the existence of close ties while also incurring obligations on the part of the beneficiary. ${ }^{51}$ Testamentary legacies did, however, encourage the fragmentation of family patrimonies. Beginning in the second century BC, several laws were implemented to avoid this, apparently with little success. I leave aside their content and the measures undertaken to enforce them (Lex Furia, Lex Voconia, Lex Falcidia), for the simple reason that, during the period studied here, these laws could be circumvented by creating a fideicommissum to which these penalties did not apply. ${ }^{52}$

The strategic utility of legacies thus gave many elite women good reasons to refuse their traditional fate of marriage and maternity. Childlessness, however, was not always a choice: infant mortality was high, and many marriages remained sterile. Contemporaries nonetheless recognized that the late imperial trend towards childlessness was largely socially conditioned. Augustinian marriage legislation, which sought to increase upper-class birth rates, was a partial reaction to this trend, though not as successful as hoped. ${ }^{53}$ It is well known that the city's elites resisted these measures, ${ }^{54}$ despite the fact that violators risked being denounced (by delatores) to treasury magistrates (aerarium). In the event of a successful conviction, denouncers were rewarded. ${ }^{55}$ In his sixth satire, Juvenal presents those who obeyed the Lex

51. See Mireille Corbier, "Idéologie et pratique de l'héritage" and "Les comportements familiaux de l'aristocratie romaine (II ${ }^{\mathrm{e}}$ siècle av. J.-C.-III ${ }^{\mathrm{e}}$ siècle ap. J.-C.)," in Parenté et stratégies familiales dans l'Antiquité romaine, eds. Jean Andreau et Hinnerk Bruhns (Rome: École française de Rome, 1990), 241-43. In particular, see her analysis of the characteristics of "vertical" and "horizontal" circulation. See also Martin, "Zur Anthropologie," 160. On the diffusion of testamentary practices in Rome and, in particular, on networks, see Stern, "The Testamentary Phenomenon," 423.

52. On this point, see Uwe Wesel, "Über den Zusammenhang der lex Furia, Voconia und Falcidia," Zeitschrift der Savigny-Stiftung für Rechtsgeschichte. Romanistische Abteilung 81 (1964): 308-16. On the Lex Voconia of 169 BC, which forbade members of the highest census class from making women heirs, see Kaser, Das Römische Privatrecht, § 66, p. 271 and $\S 68$, p. 281. On the fideicommissum as a legal instrument for circumventing the Lex Voconia, see Saller, Personal Patronage, 34. On the place of widows in the order of inheritance, see Krause, Witwen und Waisen, 82-83 and bibliography.

53. The Lex Julia de ordinibus maritendis of $18 \mathrm{BC}$ and the Lex Papia Poppea of $9 \mathrm{AD}$ are essential in this context. See: Kaser, Das Römische Privatrecht, 318-321; Nörr, "Planung in der Antike," particularly p. 315; Raepsaet-Charlier, Prosopographie des femmes, 1:2-12; and Mette-Dittmann, Die Ehegesetze des Augustus.

54. Current research generally endorses the idea that the Leges Juliae did not achieve its demographic goals. See: Susanne Dixon, The Roman Mother (London: Croom Helm, 1988), 97; Danielle Gourevitch, "Se marier pour avoir des enfants. Le point de vue du médecin," in Parenté et stratégies familiales, eds. Jean Andreau and Hinnerk Bruhns, 139-51. Mette-Dittmann, however, maintains that it would be premature to describe this family policy as a "failure": "From a wider chronological perspective, Augustus's family policy contributed to the transformation of Rome's aristocratic elite, which had already governed once, into a ruling class that was increasingly provincial and dispossessed of power. This transformation meant greater stability for the Roman system of government." Mette-Dittmann, Die Ehegesetze des Augustus, 212-13. On the problematic use of census figures in this context, see ibid., 207-14 and earlier bibliographic references to Mette-Dittmann.

55. The denouncer's reward was a share of the patrimony confiscated from the convicted. See Nörr, "Planung in der Antike," 312. On the criminal-legal dimension, 
Julia, preferring "little heirs" to the benefits offered by legacy hunters, as exceptions. ${ }^{56}$ The risks of childlessness were thus accepted and deemed minor compared to the advantages it offered.

Indeed, childlessness made it possible to enter the networks discussed above and widen one's circle of influence. Contemporaries explicitly discussed these advantages. Pliny the Elder, for example, observed that achieving the heights of authority and power (auctoritas summa et potentia) was contingent on being childless or having lost one's children at a young age. ${ }^{57}$ Similarly, Tacitus associated the frequency of visitors to one's home-a sign of power and reputation - with the household head's hospitability, available income, and lack of children. He mentioned in particular the case of Calvia Crispinilla, who "became powerful through her wealth and childlessness." ${ }^{58}$ Pliny the Younger, for his part, found it worth mentioning that his friend Asinius Rufus deliberately chose to renounce the advantages of childlessness ${ }^{59}$ which Seneca had emphasized in his Consolation to Marcia. Indeed, Seneca's intention was to comfort a mother mourning the loss of her son: he declared that, unlike in ancient times when the childless faced the prospect of a lonely old age, this condition now offered women of a certain age genuine esteem. ${ }^{60}$ This

see also David Daube, "The Accuser Under the Lex Julia de Adulteriis," Hellenika 9 (1955): 8-21.

56. Juvenal, Satires, satire 6, 38.

57. Pliny the Elder, Natural History 4:14.1.5. Champlin claims that in this context literary commonplaces of the republican period concerning decadent mores are simply being repeated. However, he overlooks the fact that a close connection between the lack of legitimate descendents and power was not emphasized prior to the late empire. See Final Judgments, 96.

58. Tacitus, "Dialogue on Oratory," trans. William Peterson, in Agricola. Germania. Dialogus (Cambridge: Harvard University Press, 1914), 6.2. That childlessness results in increased potentia can be deduced from Tacitus's observations about Calvia Crispinilla: "At the same time, the people demanded the punishment of Calvia Crispinilla. She was saved from danger, however, through various artifices on the part of the emperor, who brought ill-reputation upon himself by his duplicity. Crispinilla had taught Nero profligacy; then she had crossed to Africa to stir up Clodius Macer to rebellion, and had openly tried to bring famine to the Roman people. Afterwards she secured popularity with the entire city by her marriage with a former consul, and so was unharmed under Galba, Otho, and Vitellius. Still later she became powerful (potens) through her wealth and childlessness, which have equal weight both in good and evil times." The Histories, Books I-III, trans. Clifford H. Moore (Cambridge: Harvard University Press, 1969), I.73. On Calvia Crispinilla, see Mratschek-Halfmann, Divites et praepotentes, p. 137, no. 194. In Martial's Epigrams (1:2.32.6), Laronia is considered powerful because she is a childless and rich old widow. See Mratschek-Halfmann, Divites et praepotentes, p. 133, no. 248.

59. Pliny the Younger writes: "[Asinius Rufus] has done his duty as a good citizen, and has chosen to enjoy the blessing of a fruitful marriage at a time when the advantages of remaining childless make most people feel a single child a burden." Pliny the Younger, Letters and Panegyricus 1:4.15.3.

60. Seneca, "On Consolation to Marcia": "If I may employ a consolation by no means creditable but true, in this city of ours childlessness bestows more influence than it takes away, and the loneliness that used to be a detriment to old age, now leads to so much power that some old men pretend to hate their sons and disown their children, 
might explain why renunciation was so widely practiced at this time. It occurred either following serious disagreement with one's sons (excluding them from inheritance so that the patrimony could be bequeathed to individuals of one's own choosing) ${ }^{61}$ or following a simple denial of filiation (refusing to acknowledge kinship). These examples clearly show that in many cases, childlessness was less the result of infertility than of social strategies, notably the desire to extend one's influence beyond the narrow circles of kinship. ${ }^{62}$

\section{Legacy Hunters and Female Testators}

When examining accounts of interactions between legacy hunters and testators, it is important to remember that the kinds of acts and the behavior described were considered customary between amici. Under such circumstances, visits, small gestures of acknowledgment, and respectful exchange were taken for granted. ${ }^{63}$ These actions served as signals to outside observers, indicating the quality of the relationship that had been established. Mentioning someone in a testament was a way of acknowledging this individual as a member of one's network of friends. Current research has struggled to determine the exact role of women in these networks. ${ }^{64}$ Yet it is interesting to note that while ancient authors often refer to women receiving visits, they rarely speak of women making them. Similarly, women are mentioned as testators but never as legacy hunters.

and by their own act make themselves childless." Seneca, Moral Essays, trans. John W. Basore (Cambridge: Harvard University Press, 1935), 2:19.2.

61. One finds descriptions of such situations in Pliny the Younger's Letters: the widow Pomponia Galla renounced her son following a probable dispute (5.1); elsewhere, a father renounces his daughter (6.33). On these examples, see Tellegen's exhaustive study, The Roman Law of Succession, 82-94 and 110-118. In several of his controversiae, Seneca the Elder discusses the renunciation of sons by testament (abdictatio). See Seneca the Elder, The Elder Seneca, trans. Michael Winterbottom (Cambridge: Harvard University Press, 1974), controversies 1:2.1 and 2.4. On this topic, see also MetteDittmann, Die Ehegesetze des Augustus, 171 (for other testimonials and its bibliography). 62. On the methods used for avoiding heirs, see Mette-Dittmann's synthesis, Die Ehegesetze des Augustus, 210-11 and bibliography. On contraception, see: Keith Hopkins, "Contraception in the Roman Empire," Comparative Studies in Society and History 8-1 (1965): 124-51; Peter Brunt, Italian Manpower: 225 B.C.-A.D. 14 (Oxford: Clarendon Press, 1971), $146-55$.

63. Concerning ritual morning visits (salutationes), Goldbeck accepts the possibility that such visits with women occurred in the late first century AD but believes that Martial's accounts of such visits are a topos. Martial, he contends, offers an acerbic critique of legacy hunting: see Goldbeck, Salutationes, 73. On the terminology of amicitia relationships, see Elke Hartmann, "Euer Purpur hat unsere Togen aus dem Dienst entlassen - Zum Wandel des städtischen Klientelwesens im Rom der frühen Kaiserzeit," Millennium. Jahrbuch $\approx$ u Kultur und Geschichte des ersten Jahrtausends n. Chr. 6 (2009): 3 and bibliography. 64. On this topic, see Goldbeck, Salutationes, 84-87. 
While accepting a legacy posed no moral problem, in first-century AD literature (particularly Martial's Epigrams), one frequently encounters criticism of notorious legacy hunters who seduced their "victims" by pretending to offer their services. Why did classical authors so vehemently denounce the behavior and gestures of these "friends" — described as legacy hunters-who were nevertheless so solicitous of the elderly? Beyond complaints about specific details, the meaning of such criticism lies in the fact that these relationships were opportunistic for both parties. Herein resides their immorality. In literary sources (Seneca, Pliny the Younger, Tacitus, Epictetus, and Juvenal), ${ }^{65}$ traditional gestures and attention paid to partners were highly exaggerated: potential testators made excessive demands on their visitors, while the latter went to extremes in promoting themselves and flattering their prospective testators. ${ }^{66}$ Of these authors, the most critical is certainly Martial, who in his Epigrams alternatively adopted the perspectives of the legacy hunter and the testator, an approach that allowed him to paint a broad and-from a literary standpoint-mostly representative portrait of the relationship.

If one considers legacy hunting as a kind of game with its own set of implicit rules, it becomes clear that the players had fundamentally different goals and that this discrepancy placed them at loggerheads from the outset. The legacy hunter's goal was to secure a large sum of money as quickly and effortlessly as possible. To this end, he made a number of gestures that would have seemed spontaneous coming from a true friend: paying a visit to an old person, bringing her gifts, offering sacrifices for her recovery, ${ }^{67}$ sitting at her bedside, calling doctors, and so on. The expected "profit" was purely material, since this apparent friendliness was, needless to say, nothing more than a calculated ploy.

The testator's goal, on the other hand, was to receive a great deal of attention and live as long as possible. By frequently rewriting their testaments, testators could force potential legatees to compete with one another, placing them under considerable pressure. The testators' "gains" were extremely varied in nature. First, by receiving large numbers of visitors, they increased their social prestige, since a throng of guests (including clients) solidified one's reputation, ${ }^{68}$ regardless of whether anyone doubted that these visitors were motivated more by greed than friendship. The number of guests was considered an indicator of the extent of the host's patrimony, which was an essential component of social rank. Visits also allowed elderly testators to be cared for and noticed as well as to feel integrated into social life.

65. See the testimonials presented in Champlin, Final Judgments, 201-23.

66. This corresponds to the critique of patron-client relationships common in the works of authors during this period. See Hartmann, "Euer Purpur hat unsere Togen aus dem Dienst entlassen," particularly p. 35.

67. Juvenal writes: "No one ever kills even a quail for a man with children. If wealthy and childless Gallitta and Pacius have a hint of fever, the entire colonnade is clothed in petitions struck up in the proper way. There are people who will promise a hundred oxen-not elephants, seeing that here there are none, not even for cash. Such a beast doesn't breed in Latium or anywhere in our climate." Juvenal, Satires, satire 12, 97-104. 68. Martial, Epigrams 2:9.100.4. On the meaning of receiving large numbers of morning visitors, see Goldbeck, Salutationes, 267-273. 
Furthermore, they derived material profit from the regular gifts they received from their courtiers, which were usually edible treats. ${ }^{69}$ In one satire Juvenal speaks of a "fortune-hunting meat-market," referring to the fact that gifts of fish, meats, and other fancy foods were particularly appreciated. ${ }^{70}$ According to Martial's Epigrams, such gifts could occasionally lead a captatores to ruin. While it is true that these examples might simply be satirical hyperbole, they are nonetheless grounded in a reality that seemed obvious to contemporaries: the relationship placed a heavy financial burden on the legacy hunter, especially when it lasted longer than expected. ${ }^{71}$ The advantages sought by each party would thus seem to be quite clear. Yet to the players themselves, the benefits were not always so evident, particularly given how rigged the game could be.

Martial's Epigrams suggest that some Romans occasionally presented themselves as much wealthier than they really were, going out of their way to cultivate this image for the express purpose of reaping material and social rewards from the attention of legacy hunters. It is generally accepted that, in Martial's time, the patrimony of the upper ordines fluctuated considerably, which presumably meant that testaments were frequently modified. ${ }^{72}$ A senator living in Nero's time who was known as a bon vivant unashamedly confessed that his patrimony had been depleted by dining expenses. Consequently, Tacitus pointed out, the man had to adjust his testament on several occasions. ${ }^{73}$ Martial also refers more than once to the disappointment of legacy hunters upon discovering that an inheritance they had secured was either worthless or significantly smaller than expected. ${ }^{74}$ In this way, he alluded to the fraudulent schemes of highly sought-after testators whose conspicuous wealth was a front for actual indigence. One can even suppose, as Juvenal encouraged his readers to believe, that some of the gifts bestowed by legacy hunters had become their recipients' sole means of subsistence: a certain Aurelia, for instance, was known to resell the luxury food products a courtier had given her. ${ }^{75}$

Surrounded by a horde of legacy hunters, potential testators could rig the game in yet another way. Since captatores grew even more solicitous when the death of the individual whose fortune they sought seemed near, ${ }^{76}$ clever testators who were determined to encourage these efforts learned just when to look pale and feign sickness. ${ }^{77}$ In one epigram, Martial describes a woman who acted out her

69. Martial, Epigrams 1:2.40, 1:3.76, 2:9.48 and 2:9.88.

70. Juvenal, Satires, satire 4, 18-19; satire 5, 97 and satire 6, 40.

71. Martial, Epigrams 1:5.39.

72. On the phenomenon of impoverishment and the embarrassment it caused the upper classes, see Hartmann, "Euer Purpur hat unsere Togen aus dem Dienst entlassen," 32. 73. Tacitus, Annals 13-16 15.54.

74. See, for example, Martial, Epigrams, 2:6.66 and 9.8.

75. Juvenal, Satires, satire 5, 97-98.

76. Pliny the Younger describes Regulus's apparently appalling behavior at the bedside of Verania, Piso's widow in Letters and Panegyricus 1:2.20.

77. Martial, Epigrams 2.40 and 9.86. Pliny the Elder describes how, in Nero's time, Julius Vindex allegedly drank cumin to give himself a pale complexion, thus ensuring that there were always legacy hunters in his entourage. See Natural History 6:20.160. 
illness in a way that kept her legacy hunter at her side. The poet plays on the paradoxical nature of the elderly Naevia's weapons of seduction. Her repulsive cough becomes her way of being coquettish: "Naevia wheezes, she has a dry cough, she often sends spit into your lap. Bithynicus, do you think you have it made? You're wrong. Naevia is coaxing, not dying." 78 The interaction between testators and legacy hunters is most frequently portrayed in Martial's Epigrams, as if other sources preferred to avoid a topic considered indiscreet and indecent. Martial insinuates that women often used legacy hunters for sexual purposes. While "old"79 women's sexual tastes were frequently discussed in ancient literature, one should refrain from simply reducing this trend to a topos, lest one avoid its broader and more controversial implications. ${ }^{80}$ In both Martial's Epigrams and Juvenal's Satires, relationships of seduction frequently belong to the specific context of captatio. ${ }^{81}$ To conclude, I shall consider this point in greater detail by examining two epigrams, which add a further dimension to this attitude of moral reproach. In addition to looking at how the weakness of the elderly was abused, a point that concerned both men and women, Martial adds an issue that is directly tied to gender: the sexuality of older women.

Epigram 29 of book 11 is told from the point of view of a male legacy hunter addressing an old woman. The material goods to which the seducer aspires, and which are enumerated in the epigram's second part, leave little doubt that the narrator is indeed a legacy hunter. He seeks money, a tract of fertile land, and luxury goods that will allow him to spend ostentatiously. The woman he addresses is presented as a lecherous old lady (1. 1: "vetula") in a description that is consonant with her name, Phyllis - a name that was common among prostitutes. ${ }^{82}$ Thus, Phyllis is interested in sex. However, as the nicknames she calls her partner suggest, she also seeks love. As for the narrator, he wants nothing more than the old woman's legacy, and her behavior repulses him deeply.

78. Martial, Epigrams 1:2.26: "Quod querulum spirat, quod acerbum Naeuia tussit / inque tuos mittit sputa subinde sinus, / iam te rem factam, Bithynice, credis habere? / Erras: blanditur Naeuia, non moritur."

79. There is little certainty about the age of those Martial describes as "old" in his Epigrams. It is possible that the women he mocks in his poems were not much older than forty.

80. Women of a certain age in ancient literature were often ridiculed for their purported sexual appetite. See: Nigel M. Kay's commentary on Martial 11.29 in Martial, Book XI: A Commentary (Oxford: Oxford University Press, 1985), 134-35; Horace, Odes and Epodes, trans. Niall Rudd (Cambridge: Harvard University Press, 2004) 8.12.1-2. For an overview, see Hans Georg Oeri, Der Typ der komischen Alten in der griechischen Komödie, seine Nachwirkungen und seine Herkunft (Basel: Schwabe, 1948). An exhaustive bibliography on the topic can be found in Guillermo Galán Vioque, Martial, Book VII: A Commentary (Leiden: Brill, 2002), 75.

81. See Martial, Epigrams 1:3.32, 2:10.67, and 2:10.90. Juvenal, Satires, satire 1, 35-41 and satire $10,319-20$.

448 82. For other occurrences of this name, see Kay, Martial, Book XI, 135. 
When you start stroking my slack parts with your ancient hand, I am slaughtered by your thumb, Phyllis; and when you go on to call me 'mouse' or 'light of my eyes,' I hardly think I can recover in ten hours. You don't know how to cajole. Say 'I'll give you a hundred thousand and I'll give you some reliable acres of Setine soil; take wine, a house, boys, goldinlaid dishes, tables.' No need for fingers. That's the way to rub for my money, Phyllis. ${ }^{83}$

In this epigram, expected (because conventional) gender behavior and roles are reversed. Not only is the old woman very sexually active, which violates the convention attributing the passive sexual role to the woman, but the poet portrays her as endowed with an almost adolescent libido. She flatters her suitor-behavior that usually belongs to the legacy hunter's repertory of actions. Meanwhile, not only is the masculine narrator reduced to a passive role, but he also exhibits the weakness of an old person despite his youth. When he proves impotent, the old woman tries to revive him. The epigram's comic qualities lie in the inversion of every conceivable age and gender cliché. Both parties are clearly pursuing very different goals. Though the woman, who is presented in highly deprecatory terms, receives most of the reader's attention, the man gains little in return: his greed for material goods has compelled him to enter a relationship that is both shameful and unseemly. ${ }^{84}$

Epigram 75 of book 7 is also narrated from a masculine perspective. Once again, a narrator addresses a horrible old woman who refuses to compensate him for the sexual favors she demands" 85 : "You want to be fucked gratis, though you are an ugly hag. The thing is quite ridiculous: you want to give and not to give." 86

As in the preceding example, the text plays on the rhetoric of inverting expected social codes. ${ }^{87}$ The element of surprise results from evoking at the outset the image of a prostitute who expects to be paid for her sexual trade. In this context, offering to "be fucked gratis" is initially surprising, rather than tempting. Naturally, once the reader learns that the woman offering her favors is old and ugly, the solicited partner's passion quickly cools. The relationship of prostitution first imagined has been reversed: it is the woman who, because of her advanced age, is undesired and must pay for sexual favors. Unlike in the preceding epigram, the woman here is passive, scorned, and ridiculed. However, it is clear to the reader

83. "Languida cum uetula tractare uirilia dextra / coepisti, iugulor pollice, Phylli tuo: / nam cum me murem, cum me tua lumina dicis, / horis me refici uix puto posse decem. / Blanditias nescis: 'Dabo' dic 'tibi milia centum / et dabo Setini iugera culta soli; / accipe uina, domum, pueros, chrysendeta, mensas.' / Nil opus est digitis: sic mihi, Phylli, frica.” Martial, Epigrams 3:11.29.

84. On reading Martial, see Edward E. Best, Jr., "Martial's Readers in the Roman World," The Classical Journal 64-5 (1969): 208-12. On the possible ways in which Martial was published, see Rex Winsbury, The Roman Book: Books, Publishing and Performance in Classical Rome (London: Duckworth, 2009), 23-25 and 95-125 (on recitations).

85. On this point, see Galán Vioque's commentary in Martial, Book VII, 75.

86. "Vis futui gratis, cum sis deformis anusque. / Res perridicula est: uis dare nec dare uis." Martial, Epigrams 7.75.

87. Along the same lines, see Galán Vioque, Martial, Book VII, 431. 
that the masculine narrator has assumed the dishonorable role of a prostitute, as it is he who demands to be paid. Once again, the text emphasizes the highly polarized character of a relationship founded on diametrically opposed motivations.

In these two brief but highly representative examples, ${ }^{88}$ women look for love while men seek fortune, whether through legacies or marriage. The ugliness and lustfulness of the female characters contradict the positive image of women that is often found in ancient literature. Nor do Martial's women, who are neither young nor beautiful, neither chaste nor modest, correspond to the ideal of the attractive prostitute who is willing and available. ${ }^{89}$ In both examples, their power of seduction lies only in their wealth, even if it is rarely mentioned explicitly. It is presumably for this reason, too, that Martial neglects or alludes only discreetly to the need for legacies and dowries - a need usually deemed unworthy of men, though it is often mentioned elsewhere. ${ }^{90}$ With this inverted dramatization of sexuality, the discrepancy between moral satire and the description of a form of property transmission is stretched to its limit and to such an extent that the actual economic, social, and legal context in which male-female relations occurred all but disappears.

Women belonging to the Roman elite thus often had at their disposal considerable fortunes that were particularly sought after because they consisted of luxury objects. In some cases, these wealthy women lacked heirs, either because they had deliberately chosen not to marry or because they were widows who never had children or who had survived them-conditions, in other words, that allowed them to cultivate the bonds of horizontal sociability that could be acquired through testaments. The important place of inheritances in strategies for acquiring property explains why, in the late empire, the phenomenon of legacy hunting is so well documented. We have seen the wide variety of ways in which male and female testators profited from the social circumstances of captatio. Those whom literary sources describe as legacy hunters were, by comparison, at a relative disadvantage in terms of their profits, which were of an exclusively material character. Even the gains themselves were highly tentative. Moreover, they could never be "cashed in" when they were needed most, but only after the death of their prey.

That the moral critique found in the ancient sources was directed primarily at legacy hunters, and far less at male and female testators, can be explained by the legacy hunters' purely material goals, which, while legally permissible, were

88. Martial, Epigrams 1:1.10. For other examples, see Peter Howell, A Commentary on Book One of the Epigrams of Martial (London: Athlone Press, 1980), 130. See also: Martial, Epigrams 1:3.93, 2:9.80, and 2:10.8; Juvenal, Satires, satire 6, 136-41.

89. On this topic, see Elke Hartmann, Frauen in der Antike. Weibliche Lebenswelten von Sappho bis Theodora (Munich: C. H. Beck, 2007), 11-12.

90. Above all, philological commentaries on epigrams of this kind overlook the fact that, in reality, it is the masculine narrator who is being ridiculed for assuming the role of either an impotent materialist or a prostitute. 
nonetheless seen as violating the traditionally ethical bonds of amicitia. ${ }^{91}$ The main criticism was that in relationships between potential male or female testators and a legacy's beneficiaries, traditional signs of intimacy were feigned for purely opportunistic purposes with the primary goal of increasing one's own fortune.

Criticism of this kind is clearly apparent in the narrator's indignation towards Regulus, the legacy hunter in the letter by Pliny the Younger discussed in the introduction to this article. According to the narrator, what made Regulus's attitude particularly impudent was his assertion of a right to inherit a woman's clothing. In so doing, Regulus barely concealed the fact that his goal was to sell Aurelia's tunics. ${ }^{92}$ In light of the latent sexual interpretations of the relationship between older women and young men discussed here, the anecdote makes it possible to deduce the nature of the relationship between the testator and the testament's beneficiary. Regulus was able to pressure Aurelia to the point of compelling her to modify her testament. Pliny says that Regulus "forced" her (coegit), perhaps because he was privy to intimate details that, if revealed, could seriously threaten a society woman's reputation.

Of course, this literary portrait also belongs to a particular topos. Yet it is less the transmission of literary models that is of interest here than their actualization, meaning the way they were played out in the specific social context of late imperial Rome. While these anecdotes need not be interpreted literally, it must be noted that they dramatized the shared representations and expectations of their audience, describing an imaginary of gender relations common to Rome's elite combined with generational bonds. It should also be emphasized that these gender relations expressed in literature were intimately connected to a juridical practice that was bolstered by the entire social order: the transmission of women's property, particularly that of heirless women, like widows, and women who used testaments to designate their legatees.

This study has identified a specific regime of gender relations, that of firstcentury AD Roman elites: the interplay of law and literature within this social group makes it possible to describe a particular microcosm of gender interactions. They were at once elastic (because of the agency that legal mechanisms offered women) and restrictive (because of the collective social gaze to which these relations were subjected). The structure of these relations was chiastic: the law promoted flexible practices, while literature played a normative and ultimately moralizing role. Indeed, not only was the relationship judged shameful because of the legacy hunters' conduct, but, when the inheritance of an elderly woman was involved, it was also deemed morally offensive on sexual grounds (literally as well as figuratively): both partners were degraded by a relationship that inverted sexual norms.

91. Martial addresses the contrast between legacy hunting and true friendship: "You are childless and rich and born in Brutus consulship. Do you believe you have true friendships? You do have them, but only those you used to have when you were young and poor. Any one of your new friends is fond of your death." Martial, Epigrams 3:11.44. 92. Tellegen emphasizes Regulus's stubbornness but refuses to see his insistence as “illegitimate." See Tellegen, The Roman Law of Succession, 53. 
Yet even when the literary sources condemn both parties (a fact that negatively reveals the unusual situation of certain Roman woman), they betray a clear gender bias. When Martial in his Epigrams mocks the old women whose wealth caught the attention of legacy hunters for being demanding, domineering, and repugnant, he is only telling one side of the story: he leaves out the men who, out of necessity, chose a strategy for acquiring wealth that exposed them to countless humiliations.

Elke Hartmann Technische Universität Darmstadt 